dr Katarzyna Zimnoch

Uniwersytet $w$ Bialymstoku

Zakład Interdyscyplinarnych Badań Filologicznych

k.zimnoch@uwb.edu.pl

\title{
FORMY WSPIERANIA BIBLIOTEK W POLSCE NA PRZESTRZENI WIEKÓW - MECENAT INDYWIDUALNY, SPOŁECZNY, PAŃSTWOWY
}

\author{
Forms of THE Library SUPPORT IN POLAND OVER \\ THE CENTURIES - THE INDIVIDUAL, SOCIAL AND STATE PATRONAGE
}

\begin{abstract}
Abstrakt
Celem referatu jest przedstawienie różnych form wspierania, powstawania i funkcjonowania bibliotek w Polsce od średniowiecza po współczesność. We wcześniejszych epokach (średniowiecze, renesans, barok i oświecenie) dominowała działalność dworu, Kościoła, niekiedy rad miejskich. W XIX w. coraz większe znaczenie miały społeczne i instytucjonalne formy opieki (fundacje, towarzystwa) nad bibliotekami, w XX w. - instytucje państwowe. Wspieranie bibliotek przybierało różne formy - od inicjowania ich powstania, przez wzbogacanie księgozbioru, animowanie działalności biblioteki jako instytucji kultury, oświaty i nauki, po wsparcie osób zajmujących się działalnością biblioteczną. Przyjrzenie się temu zagadnieniu w szerokim ujęciu chronologicznym pozwoli na obserwację ewolucji form opieki nad bibliotekami.
\end{abstract}

Słowa kluczowe: historia bibliotek, formy wsparcia bibliotek, mecenat biblioteczny.

\footnotetext{
Abstract

The purpose of this work is to present various forms of support, development and functioning of the libraries in Poland from the Middle Ages to the present time. In the medieval times, the renaissance, the baroque and the enlightenment the work of the royal court as well as the church and at
} 
times the city council dominated. In the nineteenth century, the social and the institutional forms of the care over the libraries (foundations, societies) gained importance, and in the twentieth century, public institutions became significant. The support of the libraries has been taking different forms, from initiating their creation, up to enriching book collection, animating their activity as cultural, educational, and learning institutions, as well as providing aid to those involved in the library matters. Looking at that issue from a broad, chronological perspective will make it possible to observe the evolution of the libraries' supporting forms.

Keywords: history of libraries, forms of library support, library patronage.

\section{Wstęp}

Biblioteki powstawały i rozwijały swoją działalność dzięki różnym formom wsparcia osób prywatnych, instytucji, społeczeństwa i państwa. Niekiedy można mówić o mecenacie ${ }^{1}$. Początkowo dominował mecenat indywidualny, później, zwłaszcza od drugiej połowy XIX w. mecenat społeczny, zbiorowy, następnie państwowy.

Wsparcie bibliotek przejawiało się najczęściej w inicjowaniu ich powstawania i zapewnieniu warunków rozwoju, wzbogacaniu księgozbioru, animowaniu działalności biblioteki jako instytucji kultury, oświaty i nauki oraz pomocy osobom zajmującym się działalnością biblioteczną.

\section{Inicjowanie powstawania bibliotek i zapewnienie warunków ich rozwoju}

W starożytności biblioteki powstawały z inicjatywy przedstawicieli władzy i wyższych warstw społecznych. Na starożytnym Bliskim Wschodzie byli to władcy, kapłani oraz urzędnicy, w Grecji i Rzymie politycy, wodzowie, zamożni patrycjusze i uczeni. Troszczyli się o zakładanie bibliotek z różnych powodów. Chcieli zgromadzić piśmiennictwo całego świata, móc korzystać

1 Instytucja mecenatu jest zagadnieniem bardzo złożonym, zarówno na poziomie definicyjnym, faktograficznym, jak i krytycznym. Jest zjawiskiem z pogranicza różnych nauk, m.in.: historii literatury, sztuki, kulturoznawstwa, socjologii i ekonomii. Interdyscyplinarny charakter mecenatu powoduje przyjmowanie w badaniach naukowych różnych metodologii. W niniejszej pracy, instytucja mecenatu zostanie jedynie zasygnalizowana jako forma wsparcia indywidualnego, społecznego i państwowego bibliotek, w celu ukazania zmian i wskazania charakterystycznych tendencji, jakie można zaobserwować przyglądając się zjawiskom wsparcia bibliotek w ujęciu chronologicznym. 
z tego dorobku, udostępnić książki kształcącej się młodzieży oraz uczonym, by mogli spokojnie poświęcić się pracy naukowej, ale też podkreślano, że miały one służyć współczesnym i potomnym, a więc być pewnego rodzaju inwestycją w przyszłość. Fundusze przeznaczone na biblioteki pochodziły przede wszystkim od ich założycieli. Można tu przypomnieć zapis testamentowy konsula Tyberiusza Juliusza Celsusa Polemaeanusa, w którym przeznacza 25 tys. denarów na zakup książek, które miały dać początek Bibliotece Celsjańskiej².

W średniowieczu najwięcej bibliotek powstawało z inicjatywy środowiska kościelnego i uniwersyteckiego oraz dworów książęcych i możnych, gdzie skupiali się uczeni tamtych czasów. Wówczas biblioteki powstawały przede wszystkim na potrzeby Kościoła i szkolnictwa. Biblioteki klasztorne, kolegiackie, parafialne powstawały dzięki fundatorom, pomocy innych instytucji kościelnych, legatom, wymianom i darom oraz działalności własnych skryptoriów. Warto zwrócić uwagę, że część reguł zakonnych nie pozwalała posiadać na własność książek, a wszystko, co stworzyli zakonnicy należało do klasztoru. Fundatorzy uposażali klasztor, niekiedy przekazywali $\mathrm{w}$ darze cenne księgi, z czasem budowali również budynki z przeznaczeniem na pomieszczenia biblioteczne. Fundatorzy mogli liczyć na wpisanie ich do klasztornej księgi darów (liber daticus) i pamięć braci w modlitwie. W celu egzemplifikacji można podać kilka przykładów z Podlasia. Marcin Gasztołd, fundator konwentu bernardynów w Tykocinie (1479), pierwszego klasztoru na Podlasiu przekazał zakonnikom księgi liturgiczne, chórowe i homiletyczne ${ }^{3}$. W Supraślu książki ofiarowywali zarówno ktitorzy (świeccy fundatorzy w Kościele wschodnim) - Aleksander i Grzegorz Chodkiewiczowie oraz ich rodziny, np. żona Grzegorza - Katarzyna Iwanowa z Wiśniowieckich. Zapisy chętnie czynili także ci, którzy monaster supraski wybrali na miejsce spoczynku, a także trafiały tam książki ze spadków, m.in. po metropolicie Antonim Sielawie ${ }^{4}$. Z kolei dominikanie choroscy szczodrze byli obdarowywani przez Branickich. Izabela przekazała im kilka książek, w tym o tematyce medycznej, a Jan Klemens Branicki,

2 J. Tondel: Historia książki i biblioteki. Wybór źródeł. Cz. 1, (do końca XVIII w.). Toruń 1986, s. 162.

3 Jan z Komorowa: Memoriale Ordinis Fratrum Minorum. Wyd. X. Liske, A. Lorkiewicz, „Monumenta Poloniae Historica”. T. 5. Lwów 1888, s. 224-225.

4 J. Maroszek: Monografia miasta i gminy Supraśl. Supraśl 2013, s. 129-132, 217-221; Rękopisy supraskie w zbiorach krajowych i obcych. Oprac. A. Mironowicz, Katalog rękopisów supraskich. Oprac A. Mironowicz, N. Morozowa, M. Czistiakowa, E. Kierejczuk, E. Mironowicz, N. Nikołajew. Białystok 2014, s. 51-75. 
budując im $\mathrm{w}$ XVIII w. nowe budynki, pamiętał o pomieszczeniu na bibliotekę .

Z kolei zalążkiem bibliotek uniwersyteckich stawały się najczęściej odrębne księgozbiory kolegiów, zakładane dzięki darom i legatom możnowładców lub uczonych. Z czasem były też wzbogacane o wytwory własnych warsztatów i skryptoriów, a także przepisywanie podręczników w miejscowych kolegiach i bursach. Kolegium założone przez Roberta de Sorbon otrzymało od swego fundatora jego księgozbiór. Podobnie było w Akademii Krakowskiej, gdzie w początkach XV w. zaczęły powstawać biblioteki kolegiackie, tworzone przede wszystkim $\mathrm{z}$ darów i zapisów, czynionych przez profesorów. Na pierwsze miejsce wśród tych bibliotek od razu wysunęła się biblioteka Collegium Maius, która przez niemal cztery stulecia stanowiła własność tego kolegium. Dopiero za czasów Komisji Edukacji Narodowej stała się oficjalnie księgozbiorem całej uczelni. Jedna z czytelni Biblioteki, już w XVI w. nazwana została na cześć fundatora - Salą Obiedzińskiego.

Renesansowe przemiany społeczne i kulturalne szczególnie sprzyjały rozwojowi bibliotek szkolnych i uczelnianych. Obok wcześniej rozbudowanego niższego i średniego szkolnictwa katolickiego, własne sieci oświatowe zorganizowały kościoły reformowane, zwłaszcza ewangelickie. Ponadto, wśród inicjatorów bibliotek znalazły się rady miejskie (biblioteki rad miejskich, tzw. radzieckie). Przykładem może być Biblioteka Rady Miejskiej w Gdańsku, utworzona w XVII w. (dzisiejsza Biblioteka PAN). Wszyscy starali się zapewnić swoim placówkom stosowne księgozbiory ${ }^{6}$.

O mecenasach z Wielkiego Księstwa Litewskiego pisał Wojciech Wijuk Kojałowicz (Mecenates in rem literarium in Magni Ducatus Lithuaniae, Wilno 1650), zwracał on przede wszystkim uwagę na królów jako twórców bibliotek, a następnie biskupów i dostojników świeckich, eksponując przede wszystkim ich dobrodziejstwa na rzecz jezuitów, którym fundowano kolegia, bursy i biblioteki.

W renesansie na szerszą skalę zauważalny stał się rozwój pasji bibliofilskich władców, dostojników świeckich i duchownych oraz pisarzy i bogatego mieszczaństwa. Biblioteki były wyznacznikami poziomu i pozycji gospodarza. Powstawały one z funduszów ich właścicieli, licznych darów, a także jak w przypadku bibliotek królewskich, egzemplarza obowiązkowego

5 J. Maroszek: Dominikanie choroscy. „Białostocczyzna” 1994, nr 1, s. 27; S. Brzozecki: Klasztor dominikanów w Choroszczy, 1654-1832. W: Parafia rzymskokatolicka w Choroszczy 550 lat. Ksiega Jubileuszowa. Red. T. Kasabuła i A. Szot. Białystok 2009, s. 71.

6 Biblioteki rad miejskich powstawały także w Poznaniu i Toruniu. Jednak ten typ bibliotek, ze względu na słabe mieszczaństwo, nie rozwinął się w Polsce, tak jak na Zachodzie. 
(po raz pierwszy we Francji). Niektórzy władcy przyznawali bibliotece stały roczny budżet. Tak postąpił m.in. elektor Fryderyk Wilhelm w stosunku do biblioteki pałacowej w Berlinie (późniejszej Pruskiej Biblioteki Państwowej). W gromadzeniu księgozbiorów pomagali specjalni wysłannicy, których zadaniem było wyszukanie książek w całej Europie, zakupy znacznych kolekcji bibliotecznych, nabywanie książek na aukcjach. Poza tym, wysokie stanowiska często zapewniały im liczne i bogate prezenty w postaci książek. Należy pamiętać, że w wielu państwach z bibliotek królewskich wywodzą się późniejsze biblioteki narodowe.

Zmieniała się w całej Europie mentalność mecenasów kolekcjonerów, ich styl myślenia o przeznaczeniu dzieł sztuki. Pojawiły się próby udostępnienia zbiorów szerszej publiczności. Idea powszechnego (publicznego) udostępniania kolekcji prywatnych realizowana sporadycznie $\mathrm{w}$ nowożytnej Europie (np. biblioteka Medyceuszów we Florencji) od renesansu, w XVII, a zwłaszcza XVIII w. przybrała na sile. Decydujący impuls zawdzięczała oświeceniu. Liczne z zakładanych wówczas bogatych książnic albo od początku przeznaczone były do publicznego użytku, albo później uzyskiwały ten charakter. Biblioteką otwartą od 1747 r. dla publiczności w Polsce była Biblioteka Załuskich w Warszawie. Założona staraniem braci Józefa Andrzeja i Stanisława Załuskich, którzy zgromadzili pokaźny księgozbiór, nabyli i odrestaurowali pałac daniłłowiczowski z przeznaczeniem na bibliotekę i opracowali projekt wieczystej fundacji na rzecz Rzeczpospolitej z zastrzeżeniem, że po ich śmierci fundacją będzie zarządzał zakon jezuitów. $\mathrm{Na}$ rzecz tej biblioteki starano się również pozyskać pieniądze ze skarbu Rzeczypospolitej. Poseł sandomierski Sierakowski zabiegał o to słowami: „aby zaś w zapomnienie magnum opus księcia jmci biskupa krakowskiego i referendarza kor[onnego] nie poszło [...]"’ . Chodziło o kwotę 200 tys. złp.

Niestety, sejm zerwano i nie przekazano pieniędzy na bibliotekę. Po śmierci Józefa Andrzeja Załuskiego bibliotekę upaństwowiono i przemianowano na „Bibliotekę Rzeczypospolitej, Załuskich zwaną”, oddano ją zarazem pod bezpośredni zarząd Komisji Edukacji Narodowej. W 1778 r. konstytucja sejmowa przyznała jej prawo do otrzymywania bezpłatnego egzemplarza druków z terenu Korony. Dzięki tej inicjatywie bracia Załuscy przez wielu badaczy są uznawani za najwybitniejszych mecenasów tego okresu. Nie tylko ze względu na wysokość wydatkowanych przez nich sum, ale przede wszystkim inspirującą rolę, jaką odegrali w podnoszeniu stanu ówczesnej kultury.

7 Diariusz sejmu z r. 1746. Wyd. W. Konopczyński. Warszawa 1912, s. 213. 
Wobec słabości patronatu królewskiego, zwłaszcza za czasów Sasów, coraz większe znaczenie zyskiwały opiekuńcze działania magnatów. Józef A. Jabłonowski założył „Societas Jablonoviana” i zgromadził piękną bibliotekę. Jednak nie odegrała ona tak dużej roli jak Biblioteka Załuskich.

Skutecznym mecenasem kultury okazał się król Stanisław August Poniatowski. Zadbał m.in. o Szkołę Rycerską, w tym dobrze wyposażoną w niej bibliotekę, określenie zasad jej funkcjonowania, kształtowania zbiorów oraz sprowadził z Francji dwóch dobrze przeszkolonych bibliotekarzy ${ }^{8}$. Był to okres działalności indywidualnych patronów (monarchów, magnatów, dostojników Kościoła) oraz ich zbiorowych odpowiedników (m.in. klasztorów i miast)9.

Biblioteki w Polsce w XIX w. znalazły się w trudnej sytuacji. W interesie zaborców nie leżało rozwijanie oświaty i kultury polskiej. Wówczas, gdy $\mathrm{w}$ innych krajach tworzono wielkie biblioteki, na ziemiach polskich zabrakło wsparcia państwa, ale w jego miejsce pojawiła się ofiarność społeczna, a polskie dziewiętnastowieczne bibliofilstwo najwięcej uwagi poświęcało gromadzeniu i ochronie zbiorów, zwłaszcza pamiątek narodowych.

Mecenat $\mathrm{w}$ okresie zaborów odegrał doniosłą rolę w utrzymaniu i rozwoju kultury. Historycy wyróżnili nawet kategorie mecenatu w XIX w.: prywatny, państwowy, prywatno-społeczny i społeczny ${ }^{10}$. W czasach Królestwa Polskiego pojawiły się ślady mecenatu państwowego (rządowego), m.in. poprzez poczynania Stanisława K. Potockiego, kolekcjonera i ministra wyznań religijnych i oświecenia publicznego (1815-1820). Zwracał on uwagę na potrzebę dostarczenia zbiorów dla bibliotek publicznych; sam przekazał swoją kolekcję rycin tworzącej się bibliotece publicznej przy Uniwersytecie Warszawskim. Z jego inicjatywy wzbogacono ją także m.in. o księgozbiór po Feliksie Łubieńskim ${ }^{11}$. Jednak zdecydowanie największa rola $\mathrm{w}$ opiece nad kulturą narodową spoczęła na patriotycznie nastawio-

8 J. Wojakowski: Biblioteka Królewskiego Korpusu Kadetów w Warszawie. Warszawa 1989, s. 21-22.

9 Mecenat ten, zwanym niekiedy zbiorowym „kolektywnym”, instytucjonalnym, choć nie do końca sformalizowany sprawowały przede wszystkim instytucje dobrze zorganizowane i działające przez dłuższy czas, a więc zakony, zbory, rady miejskie oraz szkoły, chociaż te ostatnie same najczęściej potrzebowały wsparcia.

10 J. Dybiec: Mecenat naukowy i oświatowy w Galicji 1860-1918. Wrocław 1981, s. 112; J. Piskurewicz: Warszawskie instytucje społecznego mecenatu nauki w latach 1869-1906. Wrocław 1990, s. 14-17; A. Mężyński: Mecenat nad publikacjami naukowymi w XIX w. W: Z dziejów mecenatu kulturalnego w Polsce. Red. J. Kostecki. Warszawa 1999, s. 146.

11 J. Rudnicka: Mecenat Stanisława Kostki Potockiego w świetle jego spuścizny rękopiśmiennej. „Przegląd Humanistyczny” R. 2, nr 6 (1958), s. 170. 
nych zamożnych mecenasach. O ich zaangażowaniu świadczy udostępnianie własnych zbiorów, finansowanie przez nich konkretnych przedsięwzięć, a przede wszystkim instytucjonalne zabezpieczanie legatów, czynionych na rzecz społeczeństwa. Protektorska działalność wielkich rodów zmierzała w dwóch kierunkach: opieki nad instytucją (biblioteką, uczelnią) lub zabytkiem oraz wsparcie indywidualne pisarza, artysty.

Myśl o ocaleniu zbiorów patronowała fundacjom bibliotecznym ${ }^{12}$. Przykładem mecenatu prywatno-społecznego była ufundowana we Lwowie Biblioteka Publiczna im. Ossolińskich (1817). Środki na potrzeby tej fundacji przekazał jej założyciel Józef Maksymilian Ossoliński, ale działalność instytucji została poddana kontroli społecznej na podstawie zatwierdzonego statutu, na mocy którego wyłaniano odpowiednie gremia zarządzające. Zbiory dla biblioteki były dobierane z myślą o narodzie i zachowaniu narodowości. Powiększały się dzięki darom. Na początku do zacniejszych należała dotacja biblioteczna Lubomirskich, ale też ofiarowane w drugiej połowie XIX w. przez Antoniego Małeckiego rękopisy Juliusza Słowackiego. Fundacja Ossolińskich zapoczątkowała podobne akcje mecenatu wielkoziemiańskiego. Były to instytucje służące dobru wspólnemu, a tego typu projekty niewątpliwie są aktami mecenatu o charakterze narodowym, w dużej mierze bezinteresownym, choć nierozerwalnie związanymi z nazwiskami ich fundatorów. Warto tu wymienić biblioteki m.in.: Adama Tytusa Działyńskiego, Włodzimierza Dzieduszyckiego, Aleksandra Przeździeckiego czy Edwarda Raczyńskiego. Ten ostatni jednak nie ustanowił fundacji, bowiem na przeszkodzie stało prawo pruskie, wobec czego ofiarował bibliotekę miastu, zapewniając jej stały dochód ze swoich dóbr ${ }^{13}$. Należy też zauważyć, że dla dużych kolekcji specjalnie zaadaptowano lub wybudowano gmachy (np. dla Biblioteki Zamoyskich w Warszawie, w 1820 r. i Raczyńskich w Poznaniu w 1829 r.)

W drugiej połowie XIX w. nastąpił dynamiczny rozwój bibliotek powszechnych, przede wszystkim z inicjatywy towarzystw i licznych organizacji oświatowych, kulturalnych i fachowych. Istotną rolę odegrały powstające od początku XIX w. towarzystwa naukowe, które zakładały i utrzymywały swoje biblioteki. Niektóre z nich przetrwały do naszych czasów. Działały one dzięki ofiarności społecznej. Członkowie towarzystw,

12 A. Biernacki: Fundacje - ich rola i znaczenie w XIX stuleciu. W: Życie naukowe w Polsce $w$ drugiej połowie XIX i XX w. Organizacje i instytucje. Red. B. Jaczewski. Wrocław 1987, s. 134-146.

13 B. Kosmanowa: Edward Raczyński. Człowiek i dzieło. Bydgoszcz 1997. 
stowarzyszeń i różnych organizacji regularnie opłacali składki, przekazywali darowizny i zapisy. Można więc mówić o mecenacie społecznym, który korzystał w całości z funduszy społecznych, a organy powołane do tworzenia instytucji nimi zawiadujących kontrolowali przedstawiciele społeczeństwa. Najwcześniej i szeroko zasłużyło się Warszawskie Towarzystwo Przyjaciół Nauk (1800-1832). Jego program nastawiony był na ochronę dorobku kultury, dlatego niemalże natychmiast przystąpiono do tworzenia własnego księgozbioru, mającego częściowo zapełnić pustkę powstałą przez wywiezienie Biblioteki Załuskich do Petersburga. Inicjatywa wyszła od Aleksandra Sapiehy, który w 1802 r. przekazał Towarzystwu swój księgozbiór kodeński oraz fundusz na jego pomnożenie. Księgozbiór Biblioteki Warszawskiego Towarzystwa Przyjaciół Nauk przekazano Bibliotece PAN w Warszawie ${ }^{14}$.

W XIX w. wielu potencjalnych mecenasów ze względów politycznych opuściło ziemie polskie. Monumentalnym dziełem Wielkiej Emigracji niewątpliwie stała się Biblioteka Polska w Paryżu. Jej utworzeniu patronował książę Adam J. Czartoryski. Powołano ją jako wspólną książnicę czterech instytucji z kręgu Hotelu Lambert (Towarzystwa Literackiego, Towarzystwa Historycznego, Wydziału Statystycznego oraz Towarzystwa Naukowej Pomocy). Biblioteka otwarta została w 1838 r. Jej istnienie umożliwiały donacje. Na wydatki instytucji założyciele wpłacili początkowo 3600 franków. Pierwsze legaty wpłynęły, najpierw po zmarłym hrabim Gustawie Małachowskim, znaczne dary złożyli też: paryski księgarz Dufour oraz senator Maciej Wodziński ${ }^{15}$. Żywiono nadzieję, że po odzyskaniu niepodległości przez Polskę zbiory te zostaną do niej przewiezione. Podobne cele przyświecały twórcom muzeum i biblioteki w Rapperswilu, tzw. biblioteki wersalskiej i wielu innym. Niektóre placówki na emigracji otrzymywały status instytucji użyteczności publicznej, co dawało im szansę na dofinansowanie ich działalności przez państwo, w którym funkcjonowały (tak się stało w przypadku Biblioteki Polskiej w Paryżu).

Warto zwrócić uwagę, że w połowie w. XIX w Anglii i Stanach Zjednoczonych wydano ustawy uprawniające państwo do pobierania specjalnego podatku na wznoszenie bibliotek publicznych, których celem miało być zaspokajanie potrzeb ogółu społeczeństwa w dziedzinie czytelnictwa. Ponadto, w amerykańskim bibliotekarstwie fundusze na biblioteki

14 Podobnie działały także: Towarzystwo Naukowe Krakowskie, Towarzystwo Naukowe Płockie, Poznańskie Towarzystwo Przyjaciół Nauk.

15 A. Kowalczykowa: Mecenat literacki i artystyczny w XIX $i$ XX w. W: Z dziejów mecenatu kulturalnego w Polsce. Red. J. Kostecki. Warszawa 1999, s. 180. 
przeznaczało nie tylko państwo i samorządy, ale też prywatni ofiarodawcy (np. Adrew Carnegie przeznaczył środki na wzniesienie prawie dwóch tysięcy budynków bibliotecznych) oraz stowarzyszenia bibliotekarskie (np. Friends of N.N. Library $)^{16}$.

Wiek XX, to okres istotnego rozwoju bibliotek publicznych, realizujących zasadę powszechnej oświaty i czytelnictwa. Po 1918 r. oczekiwania w stosunku do mecenatu państwowego nad kulturą, w tym bibliotekami, były równie wielkie i idealistyczne jak wszelkie inne nadzieje Polaków, łączone $\mathrm{z}$ odzyskaną państwowością. Finansowanie bibliotek samorządowych i naukowych wzięło na siebie państwo. Wedle Marcina Czerwińskiego mecenat państwowy ma charakteryzować się tym, że jest „ściśle zinstytucjonalizowany, [...] stawia sobie cele takie jak ochrona dziedzictwa, jak jego eksponowanie, jak pomoc organizacyjna i materialna środowiska, jak wreszcie zapewnienie publiczności dostępu do dzieł, w założeniu zapewnienie tego dostępu wszystkim, którzy tego pragną"17. Niestety, brakowało wystarczających funduszy, odpowiednich ustaw i rozporządzeń. Ich przyjęcie przez władze ustawodawcze wymagało wielu lat. Należy zwrócić uwagę na niedomogi struktury organizacyjnej. Mecenat państwowy wobec nauki i kultury, jak zawsze był ubogi i ostro krytykowany.

Inne, pozapaństwowe, choć często dofinansowywane $\mathrm{z}$ budżetu państwa, formy mecenatu zbiorowego (przede wszystkim towarzystwa i fundacje) istniały przez cały okres dwudziestolecia międzywojennego, ale ich ranga się zmniejszała. Istotnie zmieniał się też charakter mecenatu prywatnego. Wówczas prywatne donacje najczęściej przekazywane były instytucjom (w tym towarzystwom naukowym czy artystycznym), np. ofiarowywanie książek dla bibliotek, były to dary ze zbiorów własnych lub zakupów (np. Adam L. Czartoryski, wnuk Adama Jerzego swoją bibliotekę w Côte de Grace we Francji przekazał Uniwersytetowi Lwowskiemu). Biblioteka Wróblewskich w Wilnie została przekazana w depozyt państwa polskiego. W miarę przejmowania opieki przez państwo i instytucje społeczne obniżał się status opiekuna prywatnego i malało jego zainteresowanie mecenasowaniem, nigdy jednak nie zanikło.

Po II wojnie światowej państwo wpływało na kulturę przez dotacje centralne, utrzymując biblioteki. 17 kwietnia 1946 r. Rada Ministrów wydała Dekret o bibliotekach i opiece nad zbiorami bibliotecznymi, na mocy którego biblioteki uznano za narodowe mienie kulturalne, służące dobru

16 S. Dahl: Dzieje książki. Wrocław 1965, s. 336.

17 M. Czerwiński: Samotność sztuki. Warszawa 1978. 
ogólnemu. W następnych latach przeprowadzano wiele zmian w strukturze organizacyjnej, wiązano biblioteki z różnymi ministerstwami i ostatecznie utworzono cztery sieci podlegające Ministerstwu Szkolnictwa Wyższego, Ministerstwu Oświaty, Ministerstwu Kultury i Sztuki oraz Polskiej Akademii Nauk. Kolejne ustawy, w których zawarto ogólne zasady finansowania bibliotek, wydane zostały kolejno w 1968 i w 1997 r. Ważną rolę wobec bibliotek publicznych w Polsce odgrywał istniejący w latach 1982-1990 Fundusz Rozwoju Kultury, który czerpał dochody z różnych źródeł, m.in.: z udziałów w dochodach budżetu, dotacji z budżetu państwa, wpłat ze środków funduszu przeciwalkoholowego oraz dobrowolnych wpłat osób fizycznych i fundacji ${ }^{18}$. Sytuacja w Polsce zaczęła się zmieniać w wyniku przeobrażeń społeczno-ustrojowych w latach 90 . XX w. i dostosowywać się do ogólnych tendencji w krajach europejskich.

Współczesne państwa stosują wobec podmiotów działających w kulturze zazwyczaj mieszany sposób finansowania. Są to elementy wsparcia bezpośredniego: dotacje i subwencje oraz różnego typu ulgi, zwolnienia i systemy zachęt o charakterze podatkowym, mające skłaniać do finansowania kultury ze źródeł pozabudżetowych i łagodzić w odniesieniu do instytucji, organizacji, twórców i producentów kultury ostrość reguł gry rynkowej. Najczęściej (z wyjątkiem Stanów Zjednoczonych) ulgi te mają znaczenie jedynie uzupełniające. Jednak warto podkreślić, że w polityce kulturalnej wielu państw przywiązuje się dużą wagę do tworzenia warunków prawnych sprzyjających rozwojowi ich instytucji kultury ${ }^{19}$.

Jeżeli chodzi o polskie biblioteki publiczne, to zasadniczo zakłada się ich finansowanie przede wszystkim $\mathrm{z}$ budżetów samorządów. Biblioteki szkolne i pedagogiczne otrzymują pieniądze $\mathrm{z}$ jednostek samorządu terytorialnego z części oświatowej subwencji ogólnej przekazywanej z budżetu państwa. Z kolei biblioteki uczelniane podlegają Prawie o szkolnictwie wyższym, a środkami na naukę dysponuje Ministerstwo Nauki i Szkolnictwa Wyższego ${ }^{20}$. Biblioteki mogą się także starać o dodatkowe fundusze z innych źródeł, m.in. fundacji, towarzystw, a od momentu wejścia Polski do Unii Europejskiej również ze środków unijnych. Dobrze znane i rozróżniane są dziś pojęcia: „mecenat”, „promocja”, „subwencja”, „sponsoring” czy

18 L. Biliński: Biblioteki publiczne końca XX w. Warszawa 2001, s. 56.

19 Z dziejów mecenatu kulturalnego w Polsce. Red. J. Kostecki. Warszawa 1999, s. 357.

20 A. Jazdon, M. Wojcińska: Zrządzanie finansami i pozyskiwanie funduszy. W: Bibliotekarstwo. Red. A. Tokarska. Warszawa 2013, s. 606-618. 
też „fundraising”. Jednak należy pamiętać, że są to źródła niepewne, tylko doraźnie wspomagające budżety bibliotek ${ }^{21}$.

Przy tej okazji warto przypomnieć słowa prof. Jadwigi Kołodziejskiej: „Utrzymywanie biblioteki nie jest świadczeniem ani łaską, nie jest też rodzajem filantropii, ale ustawowym obowiązkiem wynikającym ze strategicznych celów formułowanych przez społeczeństwo, struktury państwowe i samorządowe. Administracja państwowa poprzez legislację, programy, standardy, tak jak to się dzieje w większości krajów europejskich, musi wspierać wysiłki samorządów lokalnych. Biblioteka jest instytucją przynależną do przestrzeni publicznej, głównie jego instytucjonalnej części i jako taka współtworzy jakość naszego życia”22.

\section{Formy wsparcia}

\section{DARY I DEPOZYTY}

Na przestrzeni wieków wspieranie bibliotek przyjmowało różne formy. Zawsze ważną rolę odgrywały dary i depozyty. Już w starożytności pojawiały się sugestie, aby ofiarowywać książki bibliotekom. Na jednej z inskrypcji greckiej pojawiła się informacja o dekrecie Theodoridesa z Pireusu, który nakazywał efebom (młodzieńcom poddanym szkoleniom wojskowym) $\mathrm{z}$ Aten przekazanie książek bibliotece $\mathrm{w}$ Ptolemaion ${ }^{23}$. W średniowieczu biblioteki uniwersyteckie były wspierane darami. Bibliotekę Uniwersytetu Jagiellońskiego zasilali darami wybitni duchowni, politycy, prawnicy i teologowie. Wśród wielkich bibliofilów i dobrodziejów bibliotek można wymienić m.in.: Jana Długosza (zm. 1480), Jana Dąbrówkę (zm. 1472) oraz Jana Isnera (zm. 1410), mieszczanina krakowskiego ${ }^{24}$. Książki przekazywali uczniowie i nauczyciele. Swoje księgozbiory zapisywały bibliotekom osoby wcześniej z nimi związane, np. poeta Szymon Szymonowic, wysoko ceniony przez Jana Zamoyskiego zapisał Akademii Zamojskiej własny księgozbiór. Wiele książek było przekazywanych w formie zapisów testamentowych. Przykładem może być testament Zygmunta II Augusta ${ }^{25}$, który swoją bibliotekę w większości przekazał kolegium jezuickiemu w Wilnie (z wyjątkiem ksiąg liturgicznych, które otrzymał kościół św. Anny w Wilnie) oraz Akademii Krakowskiej (dzieła prawnicze). Od XVI w. pojawił się także dla wybranych

21 L. Biliński, dz. cyt., s. 60.

22 J. Kołodziejska: Drukowany świat. Warszawa 2003, s. 135.

23 J. Tondel: Historia książki i biblioteki. Wybór źródet. Cz. 1, dz. cyt., s. 159.

24 B. Bieńkowska: Książka na przestrzeni dziejów. Warszawa 2005, s. 64.

25 J. Tondel: Historia książki i biblioteki. Wybór źródeł. Cz. 1, dz. cyt., s. 197. 
bibliotek egzemplarz obowiązkowy. Dużą rolę odgrywali również bibliofile, poświęcający niemałe fundusze, niekiedy nawet zapożyczali się, żeby zdobyć cenne rękopisy i książki, a następnie często oni sami lub ich potomkowie obdarowywali biblioteki tymi wartościowymi kolekcjami ${ }^{26}$. Biblioteki wzbogacane były także darami lub depozytami kolekcji przekazywanymi przez osoby, które odziedziczyły je po przodkach. Próbowano je również w różny sposób zabezpieczać. Zakładane w XIX w. biblioteki ordynackie ustanawiały niepodzielność zbiorów. Wydaje się, że w ówczesnych warunkach, pewniejszym zabezpieczeniem donacji był nie dar, ale ustanowienie depozytu wieczystego. Bibliotekom swoje książki ofiarowywali również autorzy, księgarze i wydawcy.

Źródła tych darów bibliotecznych były bardzo różne. Najczęściej były to zakupy, własne lub odziedziczone po przodkach księgozbiory, ale zdarzały się również kontrowersyjne sposoby pozyskania przekazywanych książek, takie jak łupy wojenne. Pliniusz Starszy odnotował, że „po raz pierwszy zaś w Rzymie Pollio oddał na użytek publiczny księgozbiór grecki i zarazem łaciński w atrium Libertatis dodawszy wizerunki autorów, urządził to bardzo okazale za pieniądze uzyskane ze sprzedaży łupów wojennych"27. Napoleon nie dosyć, że kazał sprowadzać książki z krajów podbitych do Biblioteki Narodowej w Paryżu, to próbował także nadać pozory legalności tej grabieży, a mianowicie za śmiesznie niskie pieniądze wykupywano z bibliotek klasztornych cenne średniowieczne rękopisy i rzadkie druki ${ }^{28}$.

Należy zwrócić uwagę, że część nabytków, jakie trafiały do bibliotek $\mathrm{w}$ formie darów były to przypadkowe materiały, często przestarzałe. Księgozbiory złożone $\mathrm{z}$ darów nie pozwalają na kształtowanie profilu zbiorów zgodnie z misją bibliotek. Dlatego też zawsze ważne były fundusze na celowy rozwój instytucji. Jako przykład można podać wspominany wcześniej księgozbiór kolegiacki Uniwersytetu Jagiellońskiego, który od początku pomnażany był głównie przez dary, ale ten stan rzeczy mógł ulec pewnym zmianom dzięki kolejnym zapisom, np. w 1559 r. Benedykt z Koźmina ustanowił stały fundusz na coroczny zakup książek. Nie był on duży, ale pozwalał na pewne uniezależnianie się od dobrej woli ofiarodawców, nabywając książki, jakie uznano za przydatne dla biblioteki. Z czasem rozwój ilościowy literatury spowodował konieczność zapewnienia bibliotekom obowiązku

26 Na przykład znany, żarliwy bibliofil Tommaso Parentucelli, papież Mikołaj V (zm. 1455) obdarował Bibliotekę Watykańską doborową kolekcją rękopisów starożytnych. Biblioteka ta była pomnażana przez następców, a dzisiaj gromadzi bezcenne zasoby.

27 J. Tondel: Historia książki i biblioteki. Wybór źródeł. Cz. 1, dz. cyt., s. 165.

28 S. Dahl, dz. cyt., s. 292. 
coraz bardziej skrupulatnego dokonywania wyboru i selekcji gromadzonych książek. Obecnie biblioteki naukowe korzystają z darów prywatnych kolekcjonerów w dużo mniejszym zakresie niż dawniej.

\section{OPLATY BIBLIOTECZNE}

W bibliotekach pobierano również opłaty. Przede wszystkim były to opłaty za korzystanie ze zbiorów, uiszczane albo w formie abonamentu, albo jednorazowo za konkretne książki. Niekiedy płacono za przetrzymywanie wypożyczonych materiałów. W celu egzemplifikacji można podać kilka przykładów. W Bibliotece Załuskich przy ponownym upomnieniu czytelnika można było wypożyczyć ,jeno za rewersem i zakładem $10 \mathrm{czr}$. zł [czerwonych złotych] za każdy tom wydana będzie"29. W XIX w. w statucie Towarzystwa Biblioteki Publicznej w Warszawie wśród funduszy Towarzystwa wymieniono m.in. „opłaty od czytelników i abonentów za korzystanie $z$ książek i innych pomocy naukowych, jakiemi będzie rozporządzała Bibljoteka, opłaty za zgubione lub zniszczone książki i wydawnictwa" ${ }^{30}$. $\mathrm{W}$ dwudziestoleciu międzywojennym również często występowały opłaty abonamentowe, w różnych wysokościach, np. w Bibliotece Towarzystw Czytelń Ludowych w Toruniu opłaty nie pobierano, ale w filiach już tak w Bydgoszczy wynosiła ona 30 gr, w Mokrem 20 gr $^{31}$. Z kolei w Toruniu w Bibliotece Francuskiej „W myśl uchwały zarządu, z bibljoteki mogą korzystać także i nieczłonkowie, i to za minimalną opłatą 50 gr miesięcznie, oraz po złożeniu kaucji w wysokości 3 zł"32. Z jednej z największych w Brześciu nad Bugiem biblioteki garnizonowej mogli korzystać oficerowie i podoficerowie za uiszczeniem opłaty, a żołnierze szeregowi bezpłatnie ${ }^{33}$. Pieniądze można było także zdobywać wyprzedając dublety lub książki nieodpowiadające profilowi biblioteki. Obecnie, najczęściej pobiera się opłaty za nieterminowy zwrot wypożyczonych książek, karty biblioteczne, kaucje biblioteczne i odszkodowania za zniszczone lub zagubione materiały, a niekiedy za usługi informacyjne ${ }^{34}$.

29 J. Tondel: Historia książki i biblioteki. Wybór źródeł. Cz. 1, dz. cyt., s. 242.

30 Tamże, s. 128-129.

31 J. Tondel: Historia książki i biblioteki. Wybór źródeł. Cz. 2, (Polska od pocz. XIX w. do 1945 r.). Toruń 1989, s. 216-217.

32 Tamże, s. 219.

33 Korpus poleski. Brześć nad Bugiem 1928, s. 76.

34 Ustawa o bibliotekach (art. 14 ust. 2) zezwala na pobieranie opłat za usługi informacyjne, bibliograficzne, reprograficzne, wypożyczenia międzybiblioteczne, za wypożyczenia materiałów audiowizualnych, w formie kaucji za wypożyczone materiały bi- 


\section{DZIALALNOŚĆ I WSPÓŁPRACA BIBLIOTEK}

Warto zwrócić uwagę, że wspólne działania i projekty zawsze wpływały na obniżenie kosztów funkcjonowania bibliotek. W średniowieczu była to wymiana książek oraz tworzenie własnych skryptoriów (z czasem drukarń), które zaopatrywały $\mathrm{w}$ potrzebne materiały $\mathrm{w}$ obrębie formacji zakonnej czy instytucji. Obecnie również jest to współpraca bibliotek zwłaszcza w zakresie wymiany dubletów, tworzenia konsorcjów, dzięki którym łatwiej pozyskać fundusze i zrealizować większe projekty, stać się beneficjentami różnych programów.

Należy też pamiętać, że fundatorzy bibliotek nieraz stawali się także inicjatorami, animatorami działalności kulturalnej, w tym wydawniczej. Już w starożytności same budynki wskazywały, że biblioteka nie tylko była miejscem przechowywania książek. Jedną z części składowych budynków bibliotecznych stanowił portyk, który był ulubionym miejscem spotkań ludzi nauki, którzy mogli tutaj czytać lub prowadzić naukowe dyskusje. W bibliotece Aleksandryjskiej odbywały się publiczne konkursy poetyckie. W Bibliotece Rady Miasta w Gdańsku również stosunkowo wcześnie dostrzeżono funkcję biblioteki jako miejsca spotkań $\mathrm{w}$ celu uzyskania i wymiany informacji, wychodzono $\mathrm{z}$ nowatorskimi formami propagowania czytelnictwa oraz organizowano wykłady i spotkania dyskusyjne ${ }^{35}$. Biblioteka Załuskich miała też pełnić funkcję centrum życia kulturalnego. Organizowano w niej konkursy, zebrania naukowe i literackie oraz zawiązywano stowarzyszenia (np. Towarzystwo Literatów w Polszcze Ustanowione dla Wydawania Książek Najlepszych i Najbardziej Użytecznych, 1765-1770). W XIX w. ukazało się wiele cennych wydawnictw staraniem bibliotek przede wszystkim wielkoziemiańskich, które uzyskały status fundacji lub ordynacji.

\section{WSPARCIE MATERIALNE BIBLIOTEKARZY}

Warto zwrócić uwagę na wspieranie osób zajmujących się działalnością biblioteczną. Bardzo długo praca bibliotekarza była zajęciem dodatkowym, ale odnotowywanym w dokumentach źródłowych i wskazywanym w biografiach poszczególnych osób. W starożytności i średniowieczu biblio-

blioteczne, za niezwrócenie w terminie wypożyczonych materiałów bibliotecznych, za uszkodzenie, zniszczenie lub niezwrócenie materiałów bibliotecznych. Jednak zapis ten dotyczy bibliotek samorządowych i nielicznych bibliotek resortowych i centralnych. Zob. D. Grygrowski: Biblioteki i pieniądze. Warszawa 2015, s. 52.

35 Z. Nowak: Po starą księgę sięgam ze wzruszeniem. Gdańsk 2008, s. 263. 
tekarzami byli najczęściej uczeni i urzędnicy dworscy, w średniowieczu w klasztorach zakonnicy danego konwentu, którzy w hierarchii często zajmowali miejsce bezpośrednio po opacie, a na uniwersytetach kustosze powołani z grona profesorskiego, gdyż biblioteki pełniły głównie funkcje ośrodków i warsztatów pracy naukowej. Według Kazimiery Maleczyńskiej świadczyło to o wysokim prestiżu zajęć związanych z opieką nad księgozbiorem $^{36}$. Najczęściej swoje funkcje pełnili honorowo, chociaż znane są informacje już ze średniowiecza o wynagrodzeniach. Gdy Jakub Brzeźnicki zapisał swój cenny księgozbiór kapitule poznańskiej, dołączył szczegółowe przypisy, jakich powinna trzymać się kapituła przy zarządzaniu legatem książkowym, a pieczę nad nim mieli sprawować dwaj płatni prowizorowie $^{37}$. W Bibliotece Jagiellońskiej, w 1536 r. Bartłomiej z Lipnicy ustanowił fundację na uposażenie kustosza, który miał posiadać stopień akademicki i udostępniać książki codziennie przez dwie godziny ${ }^{38}$.

W renesansie prefektowie książnic królewskich, książęcych i możnowładczych również cieszyli się zasłużonym szacunkiem społeczeństwa i mogli liczyć na uznanie króla. Można już wskazywać wymierne korzyści. Bibliotekarze dworscy byli zazwyczaj dobrze uposażani, otrzymywali dożywotnie pensje lub urzędy ziemskie. Jedną z form ich wspierania był także system dzierżaw majętności wiejskich i plenipotencji w zarządzaniu swoimi dobrami (metodę tę częściowo wykorzystywał Jan Zamoyski wobec Szymonowica, szeroko stosowali Radziwiłłowie birżańscy). Wielu uczonych i literatów opiekujących się księgozbiorami doczekało się nawet nobilitacji, wśród nich znaleźli się m.in. Łukasz Górnicki oraz jeden z czołowych poetów polsko-łacińskich doby odrodzenia, twórca biblioteki Akademii Zamojskiej, Szymon Szymonowic. Wspomaganie takie poprawiało ich położenie społeczne i materialne, ułatwiało dalszy rozwój intelektualny i rozwijanie zdolności.

Znane są wynagrodzenia $\mathrm{z}$ okresu oświecenia. Wiadomo, że Franciszek D. Kniaźnin za pracę $\mathrm{w}$ Bibliotece Załuskich uzyskiwał rocznie 1296 zł, a potem w Puławach u Czartoryskich - 1500 zł. Można to porównać $\mathrm{z}$ innymi wynagrodzeniami ludzi kultury z tego okresu. Adam Naruszewicz otrzymał w tym czasie 32850 zł, Stanisław Trembecki 116082 zł, a z kolei Marcello Bacciarelli - 415412 zł, a Bernardo Bellotto zwany

36 K. Maleczyńska: Kształtowanie się zawodu bibliotekarza w Polsce do 1914 r. „Roczniki Biblioteczne" R. 26, nr 1/2 (1982), s. 42.

37 S. Dahl, dz. cyt., s. 241.

38 B. Bieńkowska, dz. cyt., s. 338. 
Canalettem - $18082 \mathrm{zt}^{39}$. Niestety, finansowo praca bibliotekarza była spośród wymienionych osób najsłabiej wynagradzana. Nie lepiej było w pierwszej połowie XIX w. w Ossolineum. Przeznaczone wynagrodzenia to pensje roczne dla dyrektora biblioteki w wysokości 1 tys. zł, dla kustosza - 700 zł, dla pisarza - 350 zł, dodatkowo dla służących po 144 zł. Jednak trzeba pamiętać, że w XIX w. praca w bibliotece była dla uczonych na ziemiach polskich dosyć atrakcyjna, ponieważ dawała stałe miejsce zatrudnienia i dostęp do warsztatu pracy. Zawód bibliotekarza na świecie wykrystalizował się w drugiej połowie XIX w. Wykształciły się również różne stanowiska.

Oprócz wynagrodzeń otrzymywanych za pracę, pracownicy mogą się starać o stypendia, staże i granty, które mają za zadanie doskonalić ich warsztat i dać możliwości dalszego rozwijania swoich kompetencji. Dosyć popularne, sądząc m.in. po liczbie sprawozdań opublikowanych na łamach czasopism bibliotekarskich stały się wyjazdy studyjne w ramach programu Erasmus (następnie Erasmus+).

\section{Zakończenie}

Podsumowując, we wcześniejszych epokach (średniowiecze, renesans, barok i oświecenie) dominowała działalność dworu, Kościoła, niekiedy rad miejskich. Załamanie się protektoratu królewskiego i magnackiego spowodowało, że pojawiły się nowe formy wsparcia. W XIX w. coraz większe znaczenie miały społeczne, instytucjonalne formy opieki (fundacje, towarzystwa) nad bibliotekami, w XX w. instytucje państwowe.

Należy stwierdzić, że:

1. Mecenatowi prywatnemu sprzyjała stabilizacja i dostatek ewentualnych darczyńców, rządowemu - pokój polityczny.

2. Wspieranie bibliotek przybierało różne formy, od inicjowania ich powstania, wzbogacania księgozbioru, animowania działalności biblioteki jako instytucji kultury, oświaty i nauki, po wspieranie osób zajmujących się działalnością biblioteczną.

3. W XIX w. dominującym rysem mecenatu w Polsce stało się deklaratywne i faktyczne podporządkowanie go potrzebom patriotycznym. Przejawem tego było uprzywilejowanie działań na rzecz gromadzenia materiałów dotyczących historii narodu i ochrona jej śladów materialnych, działalność kolekcjonerska.

39 A. K. Guzek: Mecenat. W: Słownik literatury polskiego oświecenia. Red. T. Kostkiewiczowa. Wrocław 1977, s. 337-338. 
Formy wspierania bibliotek w Polsce na przestrzeni wieków...

4. W XX w. mniejszy mecenat prywatny nie oznaczał osłabienia uczuć patriotycznych ani wrażliwości na sprawy kultury, ale zmieniały się zapatrywania na temat sposobów realizowania obowiązków kulturalnych w wolnym państwie.

5. W okresie powojennym, gdy upaństwowiono wydawnictwa, za formę mecenatu państwowego można uznać prawo o egzemplarzu obowiązkowym, kierowanym do kilkunastu wielkich bibliotek w kraju.

6. We wszystkich epokach najczęściej słychać było prośby o konieczność zdobycia dodatkowych środków na działalność biblioteczną i najczęściej były one niewystarczające.

\section{Bibliografia}

1. Bieńkowska B.: Książka na przestrzeni dziejów. Warszawa 2005.

2. Biernacki A.: Fundacje - ich rola i znaczenie w XIX stuleciu. W: Życie naukowe $w$ Polsce w drugiej połowie XIX i XX w. Organizacje i instytucje. Red. B. Jaczewski. Wrocław 1987, s. 134-146.

3. Biliński L.: Biblioteki publiczne końca XX w. Warszawa 2001.

4. Brzozecki S.: Klasztor dominikanów w Choroszczy, 1654-1832. W: Parafia rzymskokatolicka w Choroszczy 550 lat. Ksiega Jubileuszowa. Red. T. Kasabuła i A. Szot. Białystok 2009, s. 63-100.

5. Buchwald-Pelcowa P.: Mecenat nad piśmiennictwem i książą w dawnej Polsce. W: Z dziejów mecenatu kulturalnego w Polsce. Red. J. Kostecki. Warszawa 1999, s. 33-90.

6. Czerwiński M.: Samotność sztuki. Warszawa 1978.

7. Dahl S.: Dzieje książki. Wrocław 1965.

8. Diariusz sejmu z r. 1746. Wyd. W. Konopczyński. Warszawa 1912.

9. Dybiec J.: Mecenat naukowy i oświatowy w Galicji 1860-1918. Wrocław 1981.

10. Grygrowski D.: Biblioteki i pieniadze. Warszawa 2015.

11. Guzek A. K.: Mecenat. W: Słownik literatury polskiego oświecenia. Red. T. Kostkiewiczowa. Wrocław 1977, s. 337-338.

12. Jazdon A., Wojcińska M.: Zrzq̨dzanie finansami i pozyskiwanie funduszy. W: Bibliotekarstwo. Red. A. Tokarska. Warszawa 2013, s. 606-618.

13. Korpus poleski. Brześć nad Bugiem 1928.

14. Kosmanowa B.: Edward Raczyński. Człowiek i dzieło. Bydgoszcz 1997.

15. Kowalczykowa A.: Mecenat literacki i artystyczny w XIX $i$ XX w. W: Z dziejów mecenatu kulturalnego w Polsce. Red. J. Kostecki. Warszawa 1999.

16. Maleczyńska K.: Kształtowanie się zawodu bibliotekarza w Polsce do 1914 r. „Roczniki Biblioteczne” R. 26, nr 1/2 (1982), s. 41-56.

17. Maroszek J.: Dominikanie choroscy. „Białostocczyzna” 1994, nr 1, s. 24-27.

18. Maroszek J.: Monografia miasta i gminy Supraśl. Supraśl 2013.

19. Mężyński A.: Mecenat nad publikacjami naukowymi w XIX w. W: Z dziejów mecenatu kulturalnego w Polsce. Red. J. Kostecki. Warszawa 1999, s. 143-170. 
20. Nowak Z:: Po starą księgę sięgam ze wzruszeniem. Gdańsk 2008.

21. Piskurewicz J.: Warszawskie instytucje społecznego mecenatu nauki $w$ latach 1869-1906. Wrocław 1990.

22. Rękopisy supraskie w zbiorach krajowych i obcych. Oprac. A. Mironowicz. Katalog rękopisów supraskich. Oprac. A. Mironowicz, N. Morozowa, M. Czistiakowa, E. Kierejczuk, E. Mironowicz, N. Nikołajew. Białystok 2014.

23. Rudnicka J.: Mecenat Stanisława Kostki Potockiego w świetle jego spuścizny rękopiśmiennej. „Przegląd Humanistyczny” R. 2, nr 6 (1958), s. 157-170.

24. Tondel J.: Historia książki i biblioteki. Wybór źródeł. Cz. 1, (do końca XVIII w.). Toruń 1986.

25. Tondel J.: Historia książki i biblioteki. Wybór źródeł. Cz. 2, (Polska od pocz. XIX w. do 1945 r.). Torun 1989.

26. Wojakowski J.: Biblioteka Królewskiego Korpusu Kadetów w Warszawie. Warszawa 1989.

27. Z dziejów mecenatu kulturalnego w Polsce. Red. J. Kostecki. Warszawa 1999. 